\title{
SOCIAL DISCONTENT AND THE LABOR TROUBLES.
}

A MAjORITy of men and women find it necessary or expedient to work for others, and the question of a fair compensation for labor and of a fair and equitable division of the products of toil is a most important one. With the growing complexities of our social and industrial life, a satisfactory adjustment of these problems becomes more and more difficult. Religious animosities are dying out, or are becoming greatly softened; political discussions are losing their sharpness; but the question of capital and labor is agitated with more and more bitterness, in many instances with insurrection, violence and assassinations. Industries are crippled, commerce paralyzed, liberty violated, and cities placed at the mercy of mobs. Selfishness, inordinate greed, and reckless ambition are engendering envy, prejudice, and class hatred that prevent a calm and rational consideration of these questions.

The conflict between capital and labor could have had no reason for existence in the origin and development of capital. In the beginning man found himself alone, with only his natural faculties, "face to face with brute nature." His first struggle was to provide food, clothing, and shelter. One by one he invented simple instruments to aid in the work of his bare hands. In times of plenty he stored up against times of need. When a man gathered food enough for two meals and stored the surplus, to that extent he became a capitalist. A club or stone ax of more avail than one gathered by chance gave to its owner an advantage, and he became a property holder, and had something to protect against violence and theft. Painfully and slowly men acquired knowledge and skill, and multiplied the agencies through which their increasing wants might be supplied. They accumulated capital in tools, machinery, buildings, means of transportation, lands cleared, drained, and inclosed; and in many other products of their industry and thrift.

The crux of the social and industrial questions is distribution, 
or the division of the revenues of society among all its members. The laborer thinks he receives too little, which is doubtless often true; but the losses and risks of capital are not light or imaginary. The employing manufacturer, farmer, or great merchant is only the distributor of the final product among the various producing factors-labor, raw material, interest, taxes for various public purposes, and a score of other objects, he receiving the remainder for his services and profit. Instead of a surplus, he may be confronted with a deficit. The payments he makes and the prices he may obtain are regulated by a force greater than his own. More than 40 per cent. of all enterprises fail, but the laborer gets his pay. More than two hundred million dollars were sunk in the Panama Canal.

Our present economic system may, briefly, be said to be distribution according to contribution, or services rendered, substantial equality of opportunity, free competition, and value fixed by the law of supply and demand. Among other systems, some have proposed an equal distribution of products; these would pay every man the same, without regard to the value of the services rendered. The woman who could knit one pair of stockings should receive the same as the one who could knit four pairs. This might be a simple plan, but it would be unjust.

Men differ greatly in their abilities, and their products differ greatly in quality and value. Within the knowledge of the writer, a man doing piece work, in a shoe factory in Chicago, earns from $\$$ I 2 to $\$$ I 5 per week; another, working under precisely the same conditions and at the same prices, earns from $\$ 25$ to $\$ 30$ per week; while a third, because of irregular habits, earns but $\$ 8$ or $\$$ ro per week. To limit the production of the best man, or to compel him to share equally with the unskilful, incompetent, or lazy, would be grossly unjust and uneconomical. To make no distinction between thoughtful care and industry, and inaptitude and sloth, would be to remove that incentive to honest endeavor that has ever been the greatest factor in human progress.

Some have proposed a distribution according to needs or wants. They do not say what is meant by wants. Men's wants or 
desires vary greatly; and if such a formula were acted upon, some people's needs would increase enormously, and their efficiency would decrease in proportion.

There is a large propaganda of collectivism, which means the abolition of private property and the wage system, and the collection into a common fund of all the products of society, and its distribution among all its members according to some arbitrary method, usually by a government agent, who would be a dictator, and might be a political boss or a labor delegate. This would mean an interference with individual liberty and the tyranny of an organized section of the community, to which strong, self-reliant, liberty-loving Americans will never submit. Herbert Spencer speaks of collectivism as the coming slavery. Emile Vandervelde, in his recent book Collectivism, urges, as a means of bringing about this system and the abolition of private property, "the expropriation of the expropriators"-including in the latter class (according to the apostles of socialism) all those who, by thrift and industry, have saved in order that they might not want in sickness and old age, and that they might rear and provide for their children.

There are many people who do not believe in injustice or violence, and yet think there must be something wrong in an order which admits of such disparities in social conditions as are everywhere apparent; "which permits one class to live in comparative ease or luxury, while another suffers in poverty or is forced to incessant toil." They are groping, honestly no doubt, for some remedy through socialism, paternalism, semi-collectivism, state socialism, or a large increase of the functions of government, and the assumption or confiscation by the state, forcibly or by statute, of land, means of production, transportation, and communication.

It is easy to see the many evils and inequalities in social conditions, which all deplore; but to demonstrate clearly the cause of these conditions, to state definitely which section of society is most to blame for their existence, and to point out a remedy, is more difficult. The great social and economic questions of our modern complex life cannot be settled upon a sentimental 
basis alone. If all men were born equal, morally, physically, and intellectually, and if all were wise, virtuous, and altruistic, more ideal conditions would long ago have been attained. In numerous experiments, extending over a period of two thousand years, voluntary communistic and socialistic associations, made up of selected and sympathetic members, have proved disastrous failures; however well intentioned, the system has failed to eliminate the element of selfishness from human actions, and has dulled and dwarfed the energies of men. Compulsory communism, which must include the idle, vicious, and incompetent, would prove even more disastrous.

The complex business of modern life cannot be administered collectively. It is the experience of mankind that individuals, working under the stress of competition, are able to manage great productive and commercial enterprises more efficiently and economically than government agencies with their handicap of officialism. Collectivism, in substance, has been tried on a large scale in Russia. Alexander II. was hailed with world-wide applause when he attempted to extend liberty to his people and freed, not three, but thirty million serfs. He intrusted the carrying out of his plans to the most liberal reform element of the empire, which was especially friendly to the serfs. What has been the result? According to the best authorities, the serfs are suffering greater hardships under the mir than under the dispiaced seigneurs who were restrained by the government. Land is held collectively for the people, and the authority has become collective. " "From the time of Proudhon to the present time all the world has recognized that there is no greater tyranny than that of collectivism. Thirty million serfs are oppressed by bonds stronger than those which the edict of I86I was intended to break." Alexander II. was struck down by an anarchistic bomb after he had emancipated the serfs and tried to extend freedom to his people.

The socialistic legislation in Australia has not, according to credible reports, resulted in the general prosperity of the com-

${ }^{x}$ See De Disprades, "Present Conditions of the Peasants of Russia," American Academy of Political and Social Science, No. 34. 
munities which was predicted by its promoters. The people have been heavily taxed to meet the deficiencies in the operation of the railroads and other state ventures. In Victoria, with a population of $1,200,000$, the annual deficiency for ten years has been from three and a half to four million dollars. In New Zealand, with a population of about 725,000 , the annual deficiency for ten years has averaged about one million dollars. In New South Wales it costs as much to transport grain an average distance of two to three hundred miles to market as it does to send it from Chicago to Liverpool. The public debt has had to be scaled down, capital has been driven out, population diminished, and general prosperity checked.

A centralized government, to which the theories of state socialists lead - with but one employer, one producer, one manufacturer, and with no competition or voluntary co-operationmust assume dangerous power over the lives, conduct, and property of the people, and individual freedom must disappear. Liebknecht, the great exponent of socialism, introduced in the socialistic congress in Berlin this resolution: "The nationalization of industry for fiscal ends will set the state in the place of the private capitalists, and give it the power of imposing on the working classes the double yoke of economic exploitation and political slavery," which was adopted.

The socialists are split in two sections - the revolutionary, and the moderate or evolutionary. The latter branch seeks to gain support by urging reforms supposedly in the interest of the working people, hoping to attain their ends, gradually, through political methods. Rae says: "Notwithstanding the break of the moderate socialist (social democrats) from the revolutionary party, from habit they look tenderly upon revolutionary attempts. The recent national congress in Paris went in force to place wreaths upon the graves of the communists."

The moderate or "sentimental" socialists, who would shrink with horror from schemes of injustice, murder, and assassination, indirectly lend encouragement, perhaps unwittingly, to most dangerous tendencies and give aid and comfort to the worst 
enemies of human progress. ${ }^{x}$ Prince Kropotkin, an avowed anarchist and a prominent socialistic propagandist, was, during a recent trip to this country, well received and entertained by anarchists, socialists, as well as by many who do not share his views. This distinguished advocate of socialism put forward mild views in his speeches here, but in his book published in Paris, La conquête du pain, after speaking of the great material progress and achievements of modern society, rehearses the socialistic argument of the "robbery" of the masses by the rich which has been going on for years, and, summing up the socialistic plan, says: "If men and women bring their quota of work, they have a right to their quota of all which shall be produced by everybody, and this share will give them ease." And he continues:

In order that this ease may become a reality, it is necessary that the immense capital, cities, houses, cultivated fields, factories, avenues of communication, education, shall cease to be considered as private property, [and] must become common property. . . . . Ease for all is the end; expropriation is the means. . . . . The obstacles must be swept away by force, and it must become a reality by revolution. Whence will come the revolution? Workmen and explorers, revolutionists and conservatives, thinkers and practical men, all feel that it is at our doors.

And he proceeds at length to show how this is to be brought about, and how affairs are to be managed by the unorganized leaders of the men in revolt, and how the seized goods are to be distributed. He says it will not do to make confiscation of the property only of the rich, as some socialists advise, but that a clean sweep must be made. This would include the houses and meager savings of thrifty farmers and laborers, who must divide with the idle and vicious. He outlines his plans for seizing the homes and lands of the well-to-do, and piecing out the apartments to the "comrades." Any householder who objects "will be dealt with by the people in arms," and naturally anyone who opposes them is to be "removed." All government is to be

I "The vast majority of socialists, whose ranks shade through the different degrees into red anarchism, gather encouragement and strength from the little section of sentimentalists who compose the wing that is in sight and does the theorizing."Political Economy of Humanism. 
overthrown, and anarchy is to take its place. M. Kropotkin does not believe in government, and yet his schemes can be carried out only by some organization which implies government and a head to make it effective; and mob rule government is the most cruel and tyrannical ever imposed upon men.

On January 24, I898, M. Kropotkin lectured in Memorial Hall, London, on "Trade-Unionism." James MacDonald, secretary of the London Trades Councils, presided. According to the reports, the speeches were of a character to stir up the most bitter class-hatreds and to incite men to riot. Mr. MacDonald announced from the chair that certain publications of $M$. Kropotkin were for sale in the hall. One of these was found to be an anarchist journal called Freedom, in which men were urged to acts of violence and confiscation. Angiolilio, the murderer of Canovas, the prime minister of Spain, was commended in the highest terms. In another journal offered for sale, entitled Anarchist Morality, he said that the "great causes of moral depravity were capitalism, religion, justice, and government, and it was the duty of every friend of freedom to overthrow these sources of evil."

A journal called the Aurora, published in Spring Valley, Ill., supported by socialists, anarchists, and a considerable labor element, in April, I90I, put forth the following program:

Free work - free use of all things. Communal possession of all means of production, of ways of communication, of land, of mines, of water, etc. The abolition of private property. Doing away with government, with classes, with militarism, with privilege, with nobility and bureaucracy. Social emancipation. Anarchy.

In the last Bryan campaign a banner was carried at Sioux Falls, S. D., with the inscription: "A day will come when bankers will be hung in Boston and New York like horse thieves in Texas." Ten years ago the hanging of rich men to lamp posts with grass in their mouths was advocated in a public meeting in Hyde Park, London.

Is it strange that violence, outrages, and assassinations are becoming alarmingly frequent; that sections of the community have been encouraged to consider "the knife, the bullet, and the 
dynamite cartridge" legitimate instrumentalities through which to attain their ends; that three of our noblest presidents have fallen victims to the spirit of hate and lawlessness? The preachers of these inhuman doctrines are the moral lepers of the body politic, more dangerous than the physical, and, like them, should be segregated from the society they would destroy.

Workingmen are, by no means, all or generally socialistic; but the ranks of the socialists are recruited from the labor element. ${ }^{x}$ When it comes to a working theory of government, the socialists and anarchists are as far apart as the poles, but we find all these radical propagandas working together in socialistic and political agitation. Collectivism naturally melts into communism, and anarchism represents the extreme element of revolutionary socialism. Sombart says: "Anarchism is the bloody renaissance of the social utopia of the past."

Agitation may be good; in a worthy cause better than stagnation; but it must not run counter to the well-established principles lying at the foundation of social order and progress. While the present social order is imperfect, as all human contrivances are, it is the outgrowth of centuries of human struggle and development. Theorists and poets have dreamed of utopias and experimented in innumerable ways; communists and socialists have drenched cities in blood; anarchists and nihilists have murdered ; only to make man's upward struggle harder and slower. Violence has ever tended to block the wheels of progress. Reform has achieved much; her march may have been slow, and sometimes backward, but her triumphs are recorded on every page of history.

There would seem to be little ground for socialistic discontent in this country. Nearly all the reforms demanded by the moderate German socialists have been enjoyed here for years.

${ }^{x}$ The English trades unions in their national congresses, held successively in Norwich, Edinburgh, and Birmingham, adopted strong socialistic resolutions, and their organization sent delegates to the last International Socialistic Congress held in London. The American Federation of Labor (federation of trades unions) in its national convention, held at Kansas City in 1898 , gave the socialistic resolution the very large minority vote of 500 , and in its later congress in New Orleans the socialistic vote was relatively stronger. 
Countless thousands have come to our shores in search of civil and religious privileges and material prosperity which in lands beyond the sea they could never hope to obtain. Eminent students of civil government-De Tocqueville, Macaulay, Maine, and others - have foreseen in socialism the greatest danger to American institutions, but thus far, their fears have proved groundless. German and French democracies have leaned toward socialism, but American democracy is grounded upon individual liberty, for which our forefathers so steadfastly fought. Public sentiment in this country has ever set strongly in favor of law and order. This was shown at the time of the Pullman or Debs strike in Chicago in 1894. Before that now historic outbreak, its leaders, who expected to start a revolution, claimed that 80 per cent. of the people were with them, but the sequel showed that less than 15 per cent. were in accord with their methods. When a Democratic President called a halt to riot and destruction of property, he was promptly and overwhelmingly sustained by the whole country.

In the future, as in the past, outbreaks may occur, accompanied by lawlessness and disorder. More than two hundred millions of dollars are now being expended in New York in the construction of municipal and railroad tunnels, and in other public or quasi-public improvements; and probably proportionate amounts in other industrial and commercial centers. Hundreds of thousands of men, mostly of foreign birth or descent, are employed in this work. When these undertakings are complete, and, by reason of the exhaustion of the funds available for such enterprises, or by reason of financial depression, others are not commenced, many of the men will be thrown out of employment, and there will doubtless be suffering, discontent, and disturbances. The situation will afford the professional agitators their real opportunity; and the sentimental socialists-strong in sympathy, weak in judgment, long in theory, short in practice - are paving the way to make the outcome as disastrous as as possible.

The preachers and prophets of socialism and disorder have come to this country generally from Germany; of anarchy and 
nihilism, from Italy and Russia. Their followers are largely drawn from the foreign elements of our society, but, with a better knowledge of American institutions, the numbers of these tend constantly to decrease. The socialistic leaders complain bitterly that American workingmen have up to the present time, been slow to conform to their doctrines. Herr Kerchner, a socialistic delegate from this country to the recent socialistic congress in Paris, said in his report: "If the class-spirit is at last aroused among workingmen of America, it is owing to German immigrants; the latter are indefatigable in their task of organizing the still blind masses." The great bulk of our socialistic literature is of foreign authorship. Six of our most radical daily newspapers are printed in the German language. America is leading the world in industrial and social progress, and has no more need to go to Germany or Russia for social doctrines, the outgrowth of other times and other conditions, than for worthless machinery.

Most of the radical socialistic propaganda of the day, under various names, are reproductions of theories put forward centuries ago. The usual accessories of their agitation have been attacks upon religion, patriotism, and the family. ${ }^{x}$ Pope Leo XIII., speaking of the inequalities of which socialists complain, in his encyclical letter says :

To remedy these evils the socialists, working on the poor man's envy of the rich, endeavor to destroy private property and maintain that individual possessions should become the common property of all, to be administered by the state or municipal bodies. But their proposals are so clearly futile for all practical purposes that, if they were carried out, the workingman himself would be among the first to suffer. Moreover, they are emphatically unjust, because they would rob the lawful possessor, bring the state into a sphere that is not its own, and cause complete confusion in the country.

If there is any one thing that a study of humanity has demonstrated, it is that countries in which law has been most respected and most efficiently administered, private rights most guarded, individual effort and individual talent most encouraged, have, in

'Marx, the father of socialism, in his treatise on Secret Society in Szeitzerland, said: "We shall do well if we stir hatred and contempt against all existing institutions; we make war against all prevailing ideas of religion, of the state, of country, of patriotism. The idea of God is the keystone of perverted civilization; the true root of liberty, of equality, of culture, is atheism." 
all that makes for human progress, far outstripped those in which socialistic and revolutionary ideas have predominated. In communities where the industrious are constantly liable to be robbed of the fruits of their labors there is little inducement to save, and capital seeks other fields of investment and enterprise.

Desmolins, in his noted book Anglo-Saxon Superiority, says: "Socialistic countries are the poorest, weakest, and most backward of any in the world."

Political demagogues and socialistic speakers delight to picture the ills of society and to portray to the toilers some utopian plan which is to remove the inequalities of fortune, supply all their wants, and administer to their pleasures, with but little care or labor on their own part. ${ }^{x}$ They will not admit that there has been any improvement, and, without offering proof, assert that the benefits of progress are more and more confined to a few, that the masses are forced into deeper and deeper poverty, and that the chances of making a living are growing more and more uncertain.

Now, let us examine briefly into the actual conditions, past and present. It is true that a few enormous fortunes have been accumulated, and these have attracted much attention. In the meantime the number of moderate fortunes and the number of fairly well-to-do people has increased, relatively, faster. In regard to the assertion, so often disproved, that the "rich are growing richer and the poor poorer," Mr. Carroll D. Wright, in The Elements of Practical Sociology, says: "The doctrine is a false and misleading one; to the investigator the real statement should be, the rich are growing richer; many more people than formerly are growing rich, and the poor are growing better off." Mr. William H. Mallock and Sir Robert Giffen, after most careful examination of statistics as to the respective amounts of wealth distributed to the various classes, say that, in England, the greater part of the enormous gains of the last fifty years has

${ }^{x}$ LeCky, the English historian, in Democracy and Liberty, in speaking of American politics, says : "If the poorest, most ignorant, and most numerous class can be persuaded to hate the smaller class and to vote solely for the purpose of injuring them, the party manager will have achieved his end." 
gone to the masses. The average of earnings of each man in this country has been more than doubled in the last forty years.

We have to go back only a few generations to find in European countries the toilers living on the brink of starvation. Passing down through recent decades, we find in England and this country unmistakable improvement in the condition of the masses. The wages of almost all classes have risen, and the purchasing power of money has, with a few temporary exceptions, increased; the hours of labor are fewer, and the conditions surrounding work have been made more pleasant and healthful; the means of education, amusement, and recreation are greatly extended. Savings banks-depositors and deposits-have shown a steady growth. The houses in which the masses live are better, and are constantly increasing in comfort and value. Children, generally, pass to a higher grade of labor than that of their fathers. The voting power of the poorest man is equal to that of the richest. Political power is in the hands of the masses.

While wages have greatly advanced, the rate of interest on capital has decreased nearly one-half. Mr. Goschen, the English financier, has announced that the interest rate on consols will be $2 \frac{1}{4}$ per cent. by 1904 . Some of the recent issues of the United States securities pay less than this; at current market quotations they now pay only about $\mathrm{I} 7 / 8$ per cent.- less than one-half the rate paid twenty-five years ago.

In regard to the deplorable destitution and misery in our large cities, statistics, careful investigations, and observations show that the percentage of the very poor has not increased in the last few years, and that their conditions are not worse, although a few, contrasted with the well-to-do, may appear to be so. In London the population has tripled in the last seventy years, while the number of paupers remains about the same. The population of Chicago has more than tripled since 1876 , and the number of the very poor and destitute has less than doubled. In the consideration of this vital question agitators, and sometimes charitably disposed persons, overlook the welfare 
of the seventy millions and concentrate their thoughts upon the seven millions, or Io per cent.

Poverty cannot be abolished by philanthropy alone, nor by leading men to depend upon the state or some new social order; but it may be lessened and alleviated by lifting men to a higher level of intelligence and efficiency.

Overcrowding in certain callings and professions is responsible for many of the hardships and inequalities complained of. Clerks are frequently underpaid. The man who sells shoes receives perhaps half as much as the man who makes them. The poor shop girl gets three or four dollars a week, and her sister, the cook, six or seven dollars a week and a home (equivalent to nine or ten dollars); while her cousin, the seamstress, with some knowledge of dressmaking, may earn twelve to eighteen dollars a week. The stable man earns a dollar a day; and his brother, who has learned his trade well, may make five to six dollars a day, by shoeing horses at union rates. Many a lawyer has to struggle for his bread, while the abler and better-known man makes his $\$ 25,000$ a year. The same may be said of the doctor, and of many other professions and callings. But is the whole social system to be indicted on such charges? If too many come into a trade, society cannot guarantee to all the same wages as might be secured where their services were needed. Where there is a surplus of capital the rates of interest decline. If all the young men of a community were to take up the study of law or of medicine, while they might become good lawyers and physicians, they would probably earn less than the man employed in raising vegetables. There need be nothing to prevent these men from engaging in the cultivation of cabbage, but many of them would probably become socialists and ask the state to pare off, from the earnings of those who were engaged in supplying the world's actual wants, for their benefit, or to enact laws enjoining a wider employment of lawyers and doctors and the payment of larger fees.

The demand for labor, in this country, is generally in excess of the supply. The more skilled and efficient workmen are seldom out of employment or poorly paid. Those who 
suffer, who are poorly paid, imposed upon, preyed upon by sweaters, misled by agitators, and easily stirred up to disorder, are generally lacking in physical strength, intelligence, or skill.

Never has there been a more profound sympathy among the best and most intelligent citizens of all classes for the hardships and sufferings of the poor, and never before was so much being done to improve the condition of the employed class, as at the present time.

During the last ten or twelve years more than sixteen hundred laws bearing upon labor and industrial questions have been enacted in the forty-eight states and territories. Most of these have been constructive and along the line of progress, in solving industrial problems, in affirming individual liberty, and in protecting class from class and individuals from individuals. Some, secured through demagogic influences, may be said to be retrogressive - tending to undermine individual liberty, and destroy equality of rights by giving special privileges, rights, or exemptions to one class over another.

Of late, especially in the far West, there has grown up an exaggerated belief in the power of legislation to do all kind of things - to change the laws of nature and of human nature, to place the incompetent, the intemperate, the idle, and the improvident on the same plane as the able, the temperate, the industrious, and the thrifty, in the competition of life. Neither laws, charters, nor ordinances, however wisely devised, can insure industrial harmony and prosperity unless founded upon principles of justice and sustained by a sound, enlightened public sentiment.

It is recognized that present social and industrial conditions are susceptible of vast improvement. It cannot be claimed that all employers treat their employees fairly or justly. Great merchants and manufacturers are too often dominated by cruel commercialism, and entirely wrapped up in money, selfishness, and egotism. Not a few of the rich make a foolish display, and a wasteful, frivolous, corrupting use of their wealth. The inordinate greed of great corporations furnishes a basis for many of the current socialistic arguments. The sins of a relatively few endanger the welfare of all, and are largely responsible for the 
rumbling of unrest that is everywhere heard. On the other hand, it cannot be said that all workingmen are honest, consistent, temperate, and industrious. Professor Sombart, a philosophical socialistic writer, speaks of the "arrogance of wealth," and also calls trade unions "exclusive, narrow, brutal toward those beneath them - toward four-fifths of the outsiders - the poorer classes of workmen." $x$

It is generally recognized that unions have an important and, on the whole, a beneficent function in economic development, but the true friends of labor most deeply deplore the violence, cruelty, and wanton waste that follow in the wake of ill-advised agitation, the restriction of apprentices, and the limitation of production, by which the amount available for distribution is lessened and all suffer.

Summing up, it may be asserted that we have, in this country, under a fairly harmonious working of the existing order, gained the mastery of modern production, increased the earnings of workingmen, raised all classes to a higher level of general comfort; have broadened the avenues through which the employed become employers, the dependent independent; have made education common. and, nearer than any other nation, maintained equal justice between the strong and the weak, the rich and the poor; have endowed men with nobler altruism, and dotted the land all over with great institutions for the elevation and amelioration of the conditions of the people. It must be apparent to the most casual student of social problems that our country's continued contributions to the cause of human progress depend largely upon the good-will, real community of interests, and harmonious activities of its people; and to invoke and cultivate the spirit of envy, class prejudice, hate, and anarchy must inevitably tend to undermine the foundation upon which our institutions rest.

William A. Giles.

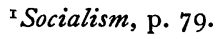

